\title{
ARQUIVOS, BIBLIOTECAS E CIÊNCIA DA INFORMAÇÃO: TEMÁTICAS ABORDADAS EM BIBLIONLINE
}

Marynice M. M. Autran

Editor de Bibionline

marynice.autran@gmail.com

Os autores que escolheram Biblionline para publicar sua produção nos brindam, neste número, com temáticas bastante diversificadas.

Nos artigos de revisão, os leitores podem conhecer as discussões, os desafios e as principais barreiras encontradas para implementar a gestão do conhecimento nas organizações; além deste, as competências profissionais do moderno profissional da informação são extensamente discutidas, à luz dos principais paradigmas que sustentam a Ciência da Informação.

Na seção relatos de pesquisa, são abordados: A mediação cultural em bibliotecas públicas e suas práticas culturais, em especial a ação cultural, fabricação cultural e animação cultural; A Encontrabilidade (findability) da Informação, explora seu atributo wayfinding (orientação espacial) no âmbito da Ciência da Informação; As memórias e configurações identitárias profissionais e pessoais de funcionários da Biblioteca Central do Centro de Ciências da Saúde (CCS) da Universidade Federal do Rio de Janeiro (UFRJ), a partir de narrativas de experiências pessoais inseridas em uma entrevista grupal; Uma análise dos diferentes aspectos relacionados às provas de concurso público para arquivista no Brasil, buscando reconhecer as relações entre os principais assuntos exigidos nas questões e o referencial teórico arquivístico; A investigação sobre as fontes de informação digitais, com ênfase nas bases de dados e $e$-books, disponibilizados aos usuários de duas bibliotecas universitárias, públicas e privadas, do Estado do Espírito Santo (ES); A biblioteca escolar é uma das figuras protagonistas nesse enredo de discussões que lhe procura conferir destaque como parte reconhecidamente legitimada na política educacional de uma nação; A proposta de uma descrição padronizada para cervejas artesanais com vistas que essa descrição facilite a organização, o acesso e a recuperação do material cerveja pelos estudiosos, comerciantes e consumidores; O artigo Usabilidade de periódicos científicos, objetiva analisar a usabilidade do processo de cadastro de autor no Open Journal System (OJS) por meio da revista BiblioCanto, que integra o Portal de Periódicos Eletrônicos da Universidade Federal do Rio Grande do Norte.

Na seção relatos de experiência são apresentadas as particularidades que ocorrem na produção e tramitação dos documentos de arquitetura de forma a promover um conhecimento detalhado acerca dos processos de formação desse tipo de arquivos. Aborda a questão da gestão de documentos no que se refere à identificação dos tipos e espécie de documentos, produção e tramitação em um escritório de arquitetura. 
De acordo com a descrição dos artigos, podemos verificar a diversidade dos artigos publicados neste número de Biblionline. Sobre bibliotecas e biblioteconomia, especificamente, são elencadas a biblioteca pública, a biblioteca universitária e a biblioteca escolar, a catalogação de cervejas artesanais e a utilização de fontes de informação digitais.

Outros temas abordados são a encontrabilidade da informação e a usabilidade do OJS, para além da gestão do conhecimento e as competências profissionais do moderno profissional da informação.

Concluindo, verificamos que a área de arquivo nos contempla com artigos que abordam, concursos públicos para arquivistas e arquivos de escritórios de arquitetura. publicado.

Desejamos que todos os leitores absorvam e utilizem o conhecimento aqui 